\title{
Introduction to symposium on rethinking farmer participation in agricultural development: development, participation, and the ethnography of ambiguity
}

\author{
Kent Glenzer • Nicole Peterson • Carla Roncoli
}

Accepted: 13 July 2010/Published online: 25 December 2010

(C) Springer Science+Business Media B.V. 2010

The topic of participation is not new to efforts to improve agricultural livelihoods and natural resource management in developing countries. Viewed as a means to encourage more democratic decision making and increase ownership and sustainability of development interventions, participation has many advocates as well as critics (see, for example, Cooke and Kothari 2001; Hickey and Mohan 2005; Moore 2000; Peters 2000; Pottier 1997). Proponents argue that a wide range of benefits results from participation, such as improved understanding, "better" decisions in terms of efficiency or quality, greater equity, conflict mitigation, and sustainability (Michener 1998; Brody et al. 2003). The papers in this symposium offer an additional set of perspectives, in the hope of establishing a deeper understanding of what influences participation and how, in turn, this affects who participates, how they participate, and what the outcomes may be. The authors employ a diverse set of methods to explore the multiple ways that participation is subject to manipulation and interpretation, examining microanalyses of behavior within their larger political, economic, and linguistic contexts.

Together, the three papers in this symposium challenge us to further broaden our view of what participation does and

K. Glenzer $(\square)$

Oxfam America, 226 Causeway St., 5th Floor, Boston,

MA 02114, USA

e-mail: kglenzer@oxfamamerica.org

\section{N. Peterson}

Department of Anthropology, Barnard College, 3009 Broadway,

New York, NY 10027, USA

e-mail: ndpeters@gmail.com

\section{Roncoli}

Department of Biological and Agricultural Engineering,

University of Georgia, Griffin, GA 30223-1797, USA should achieve, and why. Specifically, Peterson's study of participatory marine protected area planning in Loreto Bay National Park in Mexico reveals that participation disempowered certain actors who use the park for their livelihoods, but empowered others who did not participate, such as Mexican officials, international experts, and donor organizations. Taddei's study of water user committees in the Jaguaribe Valley of Northeast Brazil reveals that participation reduced the power of water committees and strengthened the hands of regional and municipal officials, centralizing power within a few groups while claiming decentralization. Paradoxically, while water committees were weakened, the participatory process also challenged long-standing patronclient relationships which were hard to influence in the past. Studying how Ugandan farmer groups discuss uncertain rainfall forecasts, Roncoli et al. suggest that attention to cultural meanings and sociolinguistic strategies brings to light the role of power relations in interpretative and deliberative processes centered on risk communication. All three studies show that the flow of benefits from participation is not easy to foresee or to measure. Moreover, in these studies, the accomplishments of participation often diverge from the actual aims of the intervention, and greatly depend on local history and context.

An ethnography of participation calls for more honest and sophisticated dialogues with participants about the very idea of participation, and asks practitioners to think beyond the present temporal and spatial boundaries of their work. Participation is constituted by absent actors and supra-local values, norms, and processes, including national policy and politics and global development and environmental discourses in the Uganda case. Within this context of deterritorialization, Peterson and Taddei insist on focusing more strongly on questions of absence and exclusion. Together, the studies in this symposium reveal 
the porosity of a strictly spatial definition of participation, disabusing us of common notions that an actor must be physically present to participate and be empowered or that an actor is excluded and disempowered by not being present.

The articles in this symposium also make a strong case for the centrality of ambiguity in participatory processes. These papers are interested in the multiplicity of meanings that accrue around the term participation and their articulation with other discourses (see also Quarles van Ufford 1993; Comaroff and Comaroff 1999). They reveal semantic boundaries purposely left blurred, outcomes and accomplishments left ill-defined. Terms of engagement are left underspecified, even to the extent that local actors are left to operationalize "participation" itself or to define the very object of discussion-as in the case of the geographic boundaries of the marine park in Mexico. In Brazil, the ambiguity surrounding terms like "politics," "democracy," and "progress" seems to be almost necessary in order to allow certain kinds and forms of participation to move forward. In Uganda and elsewhere, participation becomes a complex (and ambiguous) combination of different cultural styles of social interaction deployed in the pursuit of group consensus. Ambiguity opens spaces for greater participation while also allowing long-standing power relationships to continue operating. The result is a hybrid of empowerment and disempowerment that makes participation possible through its very polysemy.

Through a contextually engaged set of papers, this symposium offers a new object of study: the comparative ethnography of participation and its production of strategic ambiguity. As the papers show, participation can be accomplished in multiple, occasionally contradictory ways, through techniques of marginalization, exclusion, and inclusion (Peterson, Taddei) or through a simultaneous engagement of local and global practices (Roncoli et al.). The authors suggest important questions. Does the structure of international development actually demand such ambiguity? Can development-in its current institutional arrangement-actually move forward if ambiguity is resolved? The answers to these questions matter. For what these studies taken together argue is that ambiguity allows the process of participation to be negotiated by a variety of participants, leaving it to Loreto fishers and Mexican government officials, Rakai farmers and climate forecasters, Brazilian state officials and water users, to figure out the meaning and practice of participation. In appreciating participation's multiple accomplishments, its inability to be temporally or spatially bounded, and the existence of various meanings, the authors find that the process of "participation" creates important spaces for both inequities and potentialities, self-determination and disempowerment. Thus, far from being an unproblematic means to an end, participation remains a slippery concept subject to a variety of social and political influences.

\section{References}

Brody, S.D., D.R. Godschalk, and R.J. Burby. 2003. Mandating citizen participation in plan making: six strategic planning choices. Journal of the American Planning Association 69(3): 245-264.

Comaroff, J.L., and J. Comaroff. 1999. Introduction. In Civil society and the political imagination in Africa: critical perspectives, ed. J.L. Comaroff, and J. Comaroff, 1-43. Chicago, IL: University of Chicago Press.

Cooke, B., and U. Kothari. 2001. Participation: the new tyranny?. London, UK: Zed Books.

Hickey, S., and G. Mohan (eds.). 2005. Participation-from tyranny to transformation: exploring new approaches to participation in development. London: Zed Books.

Michener, V.J. 1998. The participatory approach: contradiction and co-option in Burkina Faso. World Development 26(12): 21052118.

Moore, D.S. 2000. The crucible of cultural politics: reworking "development" in Zimbabwe's eastern highlands. American Ethnologist 26(3): 654-689.

Peters, P.E. (ed.). 2000. Development encounters: sites of participation and knowledge. Cambridge, MA: Harvard Institute for International Development.

Pottier, J. 1997. Towards an ethnography of participatory appraisal and research. In Discourses of development: anthropological perspectives, ed. R.D. Grillo, and R.L. Stirrat, 203-227. Oxford, UK: Berg.

van Ufford, P.Q. 1993. Knowledge and ignorance in the practices of development policy. In An anthropological critique of development: the growth of ignorance, ed. M. Hobart, 135-160. London, UK: Routledge.

\section{Author Biographies}

Kent Glenzer, PhD has worked with international NGOs for 17 years. His research interests include the ethnography of development and development agencies, discourse and power, and critical approaches to human rights and social justice work. He currently Director of Learning, Evaluation and Accountability, at Oxfam America, focusing on the construction of measurement and inquiry systems that enable critical and multi-stakeholder assessments about impacts on the root causes of poverty and injustice.

Nicole Peterson, PhD is currently Visiting Professor of Anthropology at Barnard College. She has published another article on the Loreto marine park management in Human Organization. Her current research projects address how fishing communities have adapted to change over time, and how economic mechanisms like insurance are increasingly viewed as a way for small farmers to adapt to climate change.

Carla Roncoli, PhD is an environmental anthropologist and an Associate Research Scientist at the University of Georgia. For the last 15 years she has worked with interdisciplinary, collaborative research program focused on improving agricultural production and livelihood security in Africa. Her research interests center on the potential and constraints for application of climate predictions in agriculture, the role of participatory approaches in the communication of climate information, and the interaction of climate uncertainty, natural resource management, and decentralized governance. 